\title{
Implication of Chinese FDI in the Enjoyment of Right to Economic Development in Côte d'Ivoire
}

\author{
Cisse Amed Daouda1 ${ }^{1}$ Zakaria Dit Zan Sangare², Kone Dounamba ${ }^{3}$ \\ ${ }^{1}$ International Law, Wuhan University, Wuhan, China \\ ${ }^{2}$ International Relations, School of Political Science and Public Administration, Wuhan University, Wuhan, China \\ ${ }^{3}$ China Harbour Engineering Company LTD., Abidjan, Côte d'Ivoire \\ Email: Cisse_amed@yahoo.fr, Papy2sangare@hotmail.fr, batosdelta@hotmail.com
}

How to cite this paper: Daouda, C. A., Sangare, Z. D. Z., \& Dounamba, K. (2019). Implication of Chinese FDI in the Enjoyment of Right to Economic Development in Côte d'Ivoire. Beijing Law Review, 10, 378-390.

https://doi.org/10.4236/blr.2019.103022

Received: January 24, 2019

Accepted: April 26, 2019

Published: April 29, 2019

Copyright $\odot 2019$ by author(s) and Scientific Research Publishing Inc. This work is licensed under the Creative Commons Attribution International License (CC BY 4.0).

http://creativecommons.org/licenses/by/4.0/

(c) (i) Open Access

\begin{abstract}
Foreign investment is of great importance in the development of a country. Their participation in the economic, social, cultural and political development of a nation is undeniable. It is with this in mind that developing countries have opened their economies to foreign investment. Côte d'Ivoire, a country located in West Africa and a pillar of this zone, did not remain on the sidelines of this action. Initially, France was the economic partner of Côte d'Ivoire, then the United States and Morocco. Since a certain period, the country maintains economic relations with a new partner which is China. Chinese investments in Côte d'Ivoire are becoming more numerous, because the state offers adequate protection measures and a very favorable investment climate. Given the development objectives of the host countries, the foreign investments made in them should be in line with the realization of the right to development. A right by definition implies the right to economic, social, political and cultural development. These are provisions that are increasingly included in BIT. The purpose of this paper is to present the legal framework of the right to economic development in Côte d'Ivoire, then to determine the implication of Chinese investments in the realization of the right to economic development in Côte d'Ivoire. We used a mixed research method that is quantitative and qualitative, because we used the existing literature on the theme we approached, information collected at the embassy of China in Côte d'Ivoire, and also testimonials from some workers. We have arrived at the result to which, the legal framework of the right to economic development in Côte d'Ivoire is to improve on the one hand and the other hand, the Chinese investments in Côte d'Ivoire, even if they suffer from certain irregularities, contribute to the realization of the right to economic development of the country.
\end{abstract}




\section{Keywords}

Chinese FDI, Right to Economic Development, Côte d'Ivoire

\section{Introduction}

A Foreign Direct Investment (FDI) is defined by (IMF's, 1993) as an operation whereby an investor based in a country, called a nation of origin, acquires an asset in another state and says host country, intending to manage it over an extended period. FDI brings together two geographic and economic areas, seeking to bring them closer together to create economic benefits for the long term. They concern capital movements involving both managerial rights and partial or total ownership of local firms. The realization of FDI, as summarized by (Bost, 2004) and (Lahimer, 2009), is carried out through two types of operations: operations carried out by internal growth and activities carried out by external growth. The internal growth operations take place within the same firm between the parent company and the subsidiaries abroad. They take several forms: the creation of new local units (Greenfield investments), an extension of the production capacity of an already existing group, local reinvestment of profits, financial flows between the parent company and domestic group. Privatization programs mainly drive external growth operations, and they are subject to the condition of reaching $10 \%$ of the capital of the company concerned. They concern the acquisition of minority interests in the capital of local companies (10\% and $49 \%)$ of the money, the creation of a joint venture (50/50\%), the purchase of a majority stake in local companies (more than $50 \%$ of the capital), the acquisition of total participation.

The work on FDI is abundant, showing the interest and importance given to this instrument. Thus, theories of international trade, the industrial economy, the information economy and the economics of development have been interested in understanding, defining and explaining FDI. The question of whether foreign direct investment contributes to the realization of the right to the economic development of a country has been much in the news. While for some authors, foreign direct investment does not contribute to the economic development of a country; for others, foreign direct investment remains a significant condition for a state to enjoy the right to economic development. It is in this second wave of thought that the State of Côte d'Ivoire has registered since investment is a crucial element in the economic growth of a country. It is therefore up to each State to regulate and exercise authority over foreign investment within its national jurisdiction by its laws and regulations and conformity with its national objectives and priorities (General Assembly Resolution, 1974). ${ }^{1}$ It is on this basis that the sovereign state of Côte d'Ivoire, an emerging country located in West Africa and a pillar of this region, maintains relations with several ${ }^{1}$ Art. 2(a) 
foreign countries from all over the world and which invest in the country. Among these countries is China, a giant of the world economy. Since 1983, the two countries have enjoyed increasingly prosperous and fruitful cooperation relations which have led to the signing of numerous cooperation agreements and the realization of many Chinese direct investments in Côte d'Ivoire. As an Ivorian concerned about the importance of foreign direct investment for the state economic development but also aware of the enjoyment of Côte d'Ivoire right to economic development, we will examine the impact of Chinese direct investment on the right of economic development of the state of Côte d'Ivoire. The central question of this paper is to determine the contribution of Chinese FDI in the enjoyment of the right to economic development by the state of Côte d'Ivoire.

On the one hand is Côte d'Ivoire, the pillar of the West African region, which is seeking to be a developed country by 2020 . On the other is China, the giant of the world economy, which in his development and cooperation policies with Africa has an increasingly close relationship with African countries and Côte d'Ivoire is not left out. The cooperation and investment agreements between China and Côte d'Ivoire, covering socio-political, economic and cultural affairs, are numerous and diverse, each with its particularities.

The central question of this study is: Are Direct Chinese investments in Côte d'Ivoire made to promote the right to economic development? Sub-question is to determine the mains sectors of Chinese investments in Côte d'Ivoire, the content of the right to economic development in Côte d'Ivoire, if Ivorian labor law makes Chinese activities, is the right to economic development enforceable in Côte d'Ivoire? The answers to these questions will conduct us to make in the first part a conceptual analysis and framework of the right to economic development in Côte d'Ivoire (I). That will be the occasion to define the concept of economic development and put a light on it content then give much more information about the legal and political framework of this right in Côte d'Ivoire. The second part will aim to analyze the impact of Chinese direct investments in the enjoyment of the right to economic development in Côte d'Ivoire (II). This second part we will determine if Chinese direct investments in Côte d'Ivoire conform or not with the country enjoyment of the right de economic development.

\section{Conceptual Analysis and Framework of the Right to Economic Development in Côte D'Ivoire}

A-Concept of Right to economic development

1) Definition

The right to development was first legally recognized in the (Assembly of Heads of State and Government, 1981) and was later incorporated into the global human right framework through the Declaration on the Right to Development by the General Assembly of the United Nations. According to article 1 of the Declaration, the Right to Development is an inalienable human right by virtue of which every human person and all people are entitled to participate in, contri- 
bute to, and enjoyed, economic, social, cultural and political development, in which all human rights and fundamentals freedoms can be fully realized. ${ }^{2}$ Defined in that way, the right to development implies economic, social, cultural and political development but we are focusing our study on economic development. There is no universally accepted definition of the concept of economic development. After 1945 Economic development became a major concern. At the end of European colonialism, many former colonies and other countries with low living standards came to be termed underdeveloped countries with those of the developed countries, such as Canada and United States, Soviet Union, South Africa, Australia. Due to the rise of living standards, those countries were called developing countries. Definitions are diverse and multiple. Economic development stands for Progress in an economy or the qualitative measure of this. Economic development usually refers to the adoption of new technologies, the transition from agriculture-based to the industry-based economy, and general improvement in living standards (Business Dictionary, 2009). Economic development is also the process in which an economy grows or changes and becomes more advanced, especially when both economic and social conditions are improved (Cambridge Business English Dictionary, 2011). ${ }^{3}$ An increase in citizens' quality of life is usually the sign of a country economic development. The human development index is relating to life quality, which is an economic model that considers intrinsic personal factors not considered in economic growth, such as literacy rates, life expectancy and poverty rate. For (Finkle, 2014), ${ }^{4}$ economic development is about creating places where people want to invest, work and live. For (Krueger, 1992; HlaMyint, 1965), economic development is the transformation process of low-income national economies into modern industrialized one. Sometimes standing for economic growth, economic development is generally used to talk about an improvement in a country financial situation involving qualitative as well as quantitative improvements. The theory of economic development how primitive and poor economies can evolve into sophisticated and relatively prosperous ones is of critical importance to underdeveloped countries, and it is usually in this context that the issue of economic development is discussed. For us, the right to economic development can be defined as such human right that a country and its people can participate, contribute and enjoy the increase of living standard and economic growth.

2) Content

The declaration on the right to development does define not only development on the economic growth aspect but also the social, cultural and political perspective. The right to development includes respect for all human rights. The development process should be respectful of all human rights and fundamental freedoms and help the realization of right for all. ${ }^{5}$ The violation of that right ${ }^{2}$ Article 1 of the Declaration, the Right to Development.

${ }^{3}$ Definition of economic development.

${ }^{4}$ Former President and CEO of the international Economic Development Council.

${ }^{5}$ Article 1 and 6 of the Declaration on the Right to Development. 
constitutes an obstacle to development. ${ }^{6}$ The recognition of the right to development cannot justify the violation of human rights (UN General Assembly, 1993). Human rights are indivisible and interdependent. This entail that equal attention should be given to economic, social and cultural rights as to civil and political rights and that human rights should be addressed in an integrated manner, and not through the separate realization of individual rights. The right to development also implies the participation ${ }^{7}$ and both States and international community are required to formulate appropriate development policies. The right to development also needs social justice through fair distribution of the benefits for the individuals ${ }^{8}$ and equality of opportunity for all in the access to primary resources and services and the eradication of all social injustice. ${ }^{9}$ The right to development implies self-determination. The provision on self-determination provision on self-determination has been interpreted by some not just to refer to a reaffirmation of the independence and equality of nations, but to strengthen the rights of persons belonging to minorities and indigenous group to determine their cultures and circumstances. Finally, the right to development implies the creation of favorable conditions for the enjoyment of other civil, political, economic, social and cultural rights.

B-Framework of the right to economic development in Côte d'Ivoire

1) Legal Framework

a) The Ivorian Constitution

Former French colony, Côte d'Ivoire is independent since 1960. It was like a sovereign state, a constitution. The Republic of Côte d'Ivoire freely and solemnly approves and adapt to the Nation and humanity his Constitution ${ }^{10}$ as the fundamental law of the State, and the Preamble is an integral part. The preamble of the Republic of Côte d'Ivoire constitution reaffirms the State willing to respect all human rights. ${ }^{11}$ As soon as the right to development is a human right and Côte d'Ivoire is part to the Universal Declaration of Human Rights, the African Charter on Human and Peoples' Rights of 1981, the country and its population is entitled to enjoy is right of economic development. It is in such a way that the Civil society as one of the components of the expression of democracy contributes to the economic, social and cultural development of the Nation. ${ }^{12}$ the well-being of the entire population and all individuals on the basis of their active, free and meaningful participation in the development. Article 1(1): right of individuals and people to participate in, contribute to and enjoy development. Article 8(2) encourages popular participation".

${ }^{8}$ Article 2(3).

${ }^{9}$ Article 8(1).

${ }^{10}$ Established by Law No. 2016-8 86 on the Constitution of the Republic of Côte d'Ivoire.

${ }^{11} \mathrm{We}$ reaffirm our determination to build the rule of law in which human rights, public freedoms, the dignity of the human person, justice and good governance as defined in the international legal instruments to which Côte d'Ivoire is part, in particular, the 1945 United Nations Charter, the 1948 Universal Declaration of Human Rights, the African Charter on Human and Peoples' Rights of 1981 and its additional protocols, the Constitutive Act of the European Union. 2001, are promoted, protected and guaranteed'.

${ }^{12}$ Article 26 of the Côte d'Ivoire constitution established by Law No. 2016-8 86 on the Constitution of the Republic of Côte d'Ivoire.
} 


\section{b) African Charter on Human and Peoples' Rights}

Several conferences were organized in Africa by the UN, African governments and non-governmental organizations (NGOs) to discuss an African regional system to promote and protect human rights and fundamental freedoms in the light of international standards as well as the experiences of particular regions. One result was the African Charter, which was unanimously adopted at a meeting of African heads of state and government held in Kenya on 27 June 198. The Charter laid out a range of rights and duties that should always be respected. It also establishes the African Commission to oversee its implementation. The Commission cannot only make recommendations, which are very ignored by governments. This lack of an adequate enforcement mechanism led to calls for the establishment of an African Court on Human and Peoples Rights, and in June 1998 the Organization of African Unity (actual African Union) adopted a protocol to establish such a court. It took many Years for the Protocol to enter into force, and it was only in January 2006 that the AU Assembly of Heads of State and Government (AU Assembly) elected the 11 judges to serve in the court. The African Charter is a set of rules, called Articles, guaranteeing individual human rights and fundamental freedoms for individuals. It also ensures some of the entire peoples. The Charter is a human rights treaty. When a state ratifies an agreement, it becomes a state party to the contract. It has a legal obligation to protect the rights specified in the agreement. Many African countries have ratified these treaties and had then agreed to be bound by their regulations. The Republic of Côte d'Ivoire is a member of the African Charter, and as proclaimed by the charter, All peoples shall have the right to their economic, social and cultural development with due regard to their freedom and identity and in the equal enjoyment of the common heritage of humanity. ${ }^{13}$ States shall have the duty, individually or collectively, to ensure the exercise of the right to development. ${ }^{14}$ Regarding this disposition of the Charter and due to its ratification by the Republic of Côte d'Ivoire, the right to economic development as a fundamental right should be protected and enjoyed in the country.

c) United Nation Declaration on the Right to Development

The right to development has its roots in the African Charter on Human Rights and People's, the Charter of the United Nations, the Universal Declaration relating to Human Rights and two International Human Rights.

Through the United Nations Charter, Member States undertook to promote this right. ${ }^{15}$

The Universal Declaration on Human Rights contains some measures that became central to the international community's understanding of the right to

${ }^{13}$ Article 22(1) African Charter on Human and Peoples Rights 1981.

${ }^{14}$ Article 22(2) African Charter on Human and Peoples Rights 1981.

${ }^{15}$ Promote social progress and better standards of life in larger freedom" and "to achieve international cooperation in solving international problems of an economic, social, cultural or humanitarian character, and in promoting and encouraging respect for human rights and for fundamental freedoms for all without distinction as to race, sex, language or religion.” 
development. The Declaration ${ }^{16}$ defines the right to development. ${ }^{17}$ Regarding this disposition of the Declaration, and due to its participation by the Republic of Côte d'Ivoire, the right to economic development as a fundamental right should be protected and enjoyed in the country.

2) Political and Institutional Framework

a) Political framework: the Ministry of Planning and Development

The government's primary objective ${ }^{18}$ through the ministry of Planning and Development is to achieve a sustained double-digit sustainable growth rate and to make Côte d'Ivoire an emerging country by 2020 . This path should be established with a relatively small contribution from public investment in the productive sector and the achievement of the millennium development goals. The prime minister confirms the government's ambitions in his 2012 general policy speech to parliament. So the priorities of the state are they summarized as follows:

- poverty reduction: this is the implementation of pro-poor development policies. It involves taking into account gender equality, access to micro-finance, training and the integration of young people and women, strengthening job creation opportunities and sources and sufficient income for vulnerable populations; it also integrates food security. The human development aspect is more than ever a challenge for policymakers, and they want to address it by improving access to quality essential social services and social security.

- protection and management of the environment: it is the development of policies and instruments adapted to the protection and sustainable use of the situation; it mainly concerns the integrated management of water resources, the facilitation of access to drinking water and sanitation infrastructures.

- the promotion of the private sector to support sustainable development; it is the establishment and maintenance of substantial public investments that must serve as a basis for individual national and international initiatives.

- the restoration of social cohesion: it proceeds from the consolidation of peace through national reconciliation, the reduction of intra-community and interethnic tensions to create conditions conducive to the national social, economic development and foreign investors.

These priorities are in line with the policies to be put in place in the context of sustainable development.

b) Institutional framework: The Ivorian commission for the National Development Planning

For the preparation of the National Development Plan, an institutional structure was created. ${ }^{19}$ This framework includes an Inter-ministerial Committee for Orientation and Supervision (COS-NDP 2016-2020), ${ }^{20}$; a Technical Committee ${ }^{16}$ Declaration on the Right to Development, 4 December 1986.

${ }^{17}$ Article 1 of the Declaration on the Right to Development.

${ }^{18}$ Prime minister in his 2012 general policy speech to parliament.

${ }^{19}$ By Order No. 145/pm of 25 March 2015.

${ }^{20}$ Chaired by the Prime Minister with as Vice-President the Minister of State, Minister of Planning and Development. 
(CT-NDP 2016-2020). ${ }^{21}$ Technical Secretariat (ST-NDP 2016-2020) coordinated by the Director General of the Plan and the Fight against Poverty and Thematic Working Groups. A participatory and inclusive development process. The development of the 2016-2020 National Development Planning was based on a participatory approach. Thus, during the work of the global review of the NDP 22 2012-2015, local consultations were organized from 17 to 24 November 2014 in the capital cities of the autonomous districts and the former Districts to collect the needs and aspirations of the populations. These consultations brought together representatives from the prefectural body, decentralized authorities, decentralized administrative services, customary and religious authorities, women's and youth associations, defense and security forces, development partners, the private sector and civil society. The results of these consultations were capitalized in the development of the 2016-2020 NDP. According to the President of the Republic of Côte d'Ivoire, the NDP 2016-2020, focus on improving the conditions and quality of life of Ivorian's, including the development of quality economic infrastructure taking into account the concerns related to regional planning and the preservation of the environment. The 2016-2020 NDP also aims to promote the development of international cooperation, regional integration and the influence of Côte d'Ivoire. Thus will be built a Côte d'Ivoire where a fair justice guarantees the rights of all citizens.

In summary of all that has been said above, Development is an inalienable human right. It presents itself as a multi-faceted right that includes economic, social, cultural and political dimension. Economic development rhymes with economic growth and is reflected in an improvement of the state's mode of production. It is a right that involves participation, contribution and enjoyment of the fruits of development. As such, it is a right that deserves to be protected and realized. The legal framework of economic development in Côte d'Ivoire is based on the country constitution, the African Charter on Human and Peoples Rights, and the United Nation Declaration on the Right to Development. At the political and institutional level, there is a ministry responsible for planning and development whose role is to provide among other things the reduction of poverty, the protection, and management of the environment and the improvement of the living conditions of the population. In the same sense, the NDPC was created.

\section{Impact of Chinese Direct Investments in the Enjoyment of the Right to Economic Development in Côte D'Ivoire}

A-Harmony between Chinese direct investment and right to economic development in Côte d'Ivoire

1) Economic growth

One of the primary objectives of the Ivorian government is to be a developed country in 2020. To do so, this involves several political, institutional and eco-

${ }^{21}$ Headed by the Prime Minister's Cabinet Director.

${ }^{22} \mathrm{NDP}$ (National Development Planning). 
nomic measures put in place. Conscious of the fact that foreign investments are a significant condition for the economic development of a State and consequently for the enjoyment of the right to economic development, the Ivorian State has opened its economy to several investors. Among these is the giant of the Asian continent, China. To date, China is Côte d'Ivoire's third largest economic partner. The volume of Chinese investments in Côte d'Ivoire is growing steadily over the years. These investments are around $14.9 \%{ }^{23}$ China has embarked on some investment projects that it funds through donations and loans, including through Exim Bank of China. This was close to 920 billion FCFA (1.4 billion euros) of investments in progress in the country in September 2015, which currently represents $28 \%$ of current external financing injected in Côte d'Ivoire. During the celebration of the 35th anniversary of diplomatic relations between China and the Republic of Côte d'Ivoire, the head of the Chinese foreign mission in Côte d'Ivoire has not failed to give an opinion on the corporation. He stresses that the Sino-Ivorian cooperation is win-win and mutual one that benefit to both countries. ${ }^{24} \mathrm{He}$ also revealed that "Investments made by Chinese companies in Côte d'Ivoire have increased. According to incomplete statistics, the volume of Chinese investments to Côte d'Ivoire amounts to 200 million US dollars.

By this fact, we can see the importance of the volume of Chinese investments in Côte d'Ivoire. They contribute to the economic growth of the country and consequently to the enjoyment of its right to economic development; we can affirm that the Chinese direct investment in Côte d'Ivoire is in harmony with the satisfaction of the right to the economic development of the country.

2) Creation of infrastructures

China pledged to increase investment on the black continent at the 2015 Summit of the Forum on China-Africa Cooperation in Johannesburg. Thus, it had planned to increase the volume of its direct investments in Africa to 100 billion dollars by 2020 against 32.4 billion in 2014 .

Just after this summit, joining the deed with the word, China began to finance many projects and infrastructures in Africa. Côte d'Ivoire, in West Africa, is one of the countries currently benefiting from these investments.

The Abidjan-Bassam highway, whose construction is now complete, is a perfect example. China Machinery Engineering Corporation has been the prime contractor for this sizeable $2 \times 3$ lane toll lane, more than $42 \mathrm{~km}$ long. The cost of the works was about $\$ 104$ million. The commissioning of this motorway makes it easy to connect Abidjan, the economic capital of the country, to the seaside resort of Grand-Bassam, thus developing the tourism sector in this area.

By its desire to participate in the development of African countries, a commitment reiterated in the New Silk Roads initiative; China has undertaken since

\footnotetext{
${ }^{23}$ Data collected during my working time at Chinese embassy in Côte d'Ivoire (January 2017-September 2017).

${ }^{24}$ His Excellency Mr. Tang WEIBIN, China Embassad or in Côte d'Ivoire (2015-2019)
} 
2015 the extension of the free port of Abidjan. China Communications Construction Company manages the yard. The financing, costing about 800 million dollars, was obtained from the Chinese export-import bank Exim bank. The port extension works, scheduled to be completed in 2020, concern the widening and deepening of the Vridi Canal to accommodate vessels of 25,000 to 50,000 tons and more than 300 meters in length. Thus, the free port of Abidjan will be able to catch up with the accumulated investments in recent years and raise its level of competitiveness in the sub-region. The Olympic Stadium of Ebimpé is the other architectural gem that China has funded entirely in Côte d'Ivoire. The construction of this sports arena located in Anyama, a suburb of the economic capital, began in January 2017. The stadium to be delivered in 2019 has cost about 140 million dollars to China. Côte d'Ivoire, which plans to host the finals of the 2021 African Cup of Nations, welcomes the advent of this stadium which has more than 60 thousand seats.

The construction of four state-of-the-art high schools in Côte d'Ivoire by China is also the materialization of the excellent health of Sino-Ivorian relations. Sun Liang, ${ }^{25}$ had initiated a convention to this effect during a meeting with KandiaCamara ${ }^{26}$ in 2016. If the construction work of these institutions has not started yet, their funding is already ready. It amounts about 28 million dollars (HlaMyint, 1965). Grand Bassam must host one of these high schools.

Except for these significant projects, China has begun renovating the Ivorian road network, particularly in the north, and is currently paving the Odienné-Gbéléban road. ${ }^{27}$ The cost of the works is about 76 million dollars, including a contribution of 38 billion CFA francs from China.

China did not stop there. Since 2015, the country has pledged to help Côte d'Ivoire strengthen its electricity network. The cost of the project is \$ 819 million. It involves the construction of 14 new high voltage substations, the construction of $1555 \mathrm{~km}$ of transmission lines and the supply of electrical equipment, not to mention the electrification of 500 localities.

All these large Chinese yards completed or being completed in Côte d'Ivoire demonstrate that Sino-Ivorian cooperation is in good shape and Chinese investments are made to participate in the right of economic development as soon as Côte d'Ivoire people enjoy.

B-Incompatibility of Chinese direct investments with the right to economic development In Côte d'Ivoire

1) Employment, training, and Cooperation with national investors

"The right to development (...) gives everyone the right to participate in, ${ }^{28}$ "that includes popular participation in the development and violation of that disposition constitutes a violation of the right to development. However, the fact is that in the execution of investments projects in Côte d'Ivoire and most of the

${ }^{25}$ Chinese economic and commercial adviser.

${ }^{26}$ Ivorian education Minister.

${ }^{27}$ Located in northwestern Côte d'Ivoire.

${ }^{28}$ Article 2 of the Declaration on the Right to Development. 
African countries, Chinese investors use to come with the Chinese workforce. While they have to" recruits as a priority the national workforce and contributes to increasing the qualification of his local collaborators, in particular through continuous training, the development of national skills through advanced training courses. ${ }^{229}$ In that way, even if these investment projects are done in favor of the right to economic development, the Ivorian cannot "participate in" the development. Doing so, Chinese investors are violating the right to development. This is the same problem with national investors are facing because Chinese investors also come with their material from China while they have to "favors the use of local suppliers and subcontractors with whom he has a mutually beneficial relationship. The investor contributes to the reinforcement of the know-how of the local staff notably by the formation and the transfer of technologies." ${ }^{30}$

2) Poor remuneration of workers and difficult working standards

Most of the time Chinese companies in Africa are not in good standing with some points of labor law. I heard many Ivorian workers complaining about their working conditions and poor remuneration. A worker explains that "after my hiring in 2007, they renewed my CDD a second time, which is forbidden in Côte d'Ivoire. With other employees, we protested and signed a permanent contract. The boss does not pay social security contributions for employees, so we do not contribute to our retirement, and we do not have health insurance. This action constitutes a violation of the human right to health. The worker also explains that to his Chinese superiors, they have mainly communication problems. They ask for things by shouting and behaving as if they have all the rights over us. They openly distribute money to some employees, which makes others angry. Another worker explains that he arrived in the company ${ }^{31}$ in 2001 and the salary went from 18,000 FCFA to 35,000 FCFA in 11 years thanks to new legislation of the government [in 2011, the monthly minimum wage was set at 35,000 FCFA, 54 euros by the government. But today, despite his seniority, he earns the same as recruits, which he find very unfair. Since there is no job, he has no choice but to stay. He works at the store 10 hours a day. He prepares packages ordered by foreign customers. He is not enjoying the job but has no choice. ${ }^{32}$ They do not receive a fixed salary, but the piece pays them. The bosses understood that it was profitable! They also know that people are forced to accept low wages if they want to make a living. The last testimony is from Mitterand $\mathrm{d}^{33}$ "I work from $6 \mathrm{~h}$ to $16 \mathrm{~h}$ from Monday to Sunday under a blazing sun. We have several times demanded workers' outfits for the bosses, because we see well-equipped workers on other Chinese shipyards. But apart from gloves and a vest that they do not even want to replace when they are damaged, they have never provided us with boots or blouses, or even helmets that would protect us from the sun" he said.

As soon as the right to development aims to the constant improvement of the

\footnotetext{
${ }^{29}$ Article 26 Côte d'Ivoire investment Code.

${ }^{30}$ Article 23 Côte d'Ivoire investment Code.

${ }^{31}$ Chinese company manufacturing synthetic hair locks.

${ }^{32}$ "I am less to be pitied than fellow workers who make wicks with very noisy machines," he said.

${ }^{33}$ Mitterrand K, 26 years old, is a worker in a Chinese company that renovates roads.
} 
well-being of the entire population and all individual and Chinese investors in the execution of them investments project are not contributing to that, they are violating the right of economic development.

\section{Conclusion}

The right to development is implicitly addressed in the Côte d'Ivoire constitution. As a signatory to the ACHPR and the UNDRTD, the country is supposed to ensure the respect and realization of this right. At the political and institutional level, there is a ministry responsible for planning and development whose role is to provide among other things the reduction of poverty, the protection, and management of the environment and the improvement of the living conditions of the population. In the same sense, the NDPC was created.

However, unlike some African countries that have explicitly recognized the right to development in their constitutions so that it has a strength similar to that of foreign investment, Côte d'Ivoire has merely much more political than legal understanding of development.

Concerning Chinese direct investments in Côte d'Ivoire, there is of great importance relevant to their contribution to the Ivorian government's goal to be a developed country in 2020. Chinese investments in Côte d'Ivoire contribute to the consolidation of the state in its leading position in the West African zone. The primary goal of this study is to determine the involvement of Chinese direct investment in the enjoyment of the right to economic development. We realize that in many cases and in a transparent way, Chinese investments in Côte d'Ivoire, even if suffering from certain irregularities by violating specific prescriptions of the Ivorian law, are realized so that the Ivorian populations "participate in, contribute to, and enjoy economic, social, cultural and political development." However, for a better contribution of the right to the economic development of Côte d'Ivoire, investors must respect the labor legislation in Côte d'Ivoire as well as the requirements of the Investment Code.

\section{Conflicts of Interest}

The authors declare no conflicts of interest regarding the publication of this paper.

\section{References}

Assembly of Heads of State and Government Adopted Decision 115 (XVI) of June 27, 1981 and Intered into Force in 1981, African Charter on Human and Peoples Rights. http://www.corteidh.or.cr/tablas/4558.pdf

Bost, F. (2004). Les Investissements Directs Etrangers, Révélateurs de l'Attractivité des Territoires à l'Echelle Mondiale. Paris: Université Paris-X-Nanterre. https://mappemonde-archive.mgm.fr/num3/articles/art04301.pdf

Business Dictionary (2009). http://www.businessdictionary.com

Cambridge Business English Dictionary (2011). Economic Development. https://dictionary.cambridge.org/dictionary/english/economic-development 
Finkle, J. (2014). What Is Economic Development?

https://search.proquest.com/openview/c313381d8227a75448acaf8db2833cab/1.pdf?pqorigsite $=$ gscholar $\& \mathrm{cbl}=44217$

General Assembly Resolution 3281 (XXIX) of 12 December 1974 Containing the Charter on Economic Rights and States Duties.

http://digitalcommons.law.uga.edu/cgi/viewcontent.cgi?article=2243\&context=gjicl

HlaMyint (1965). The Economics of Developing Countries.

https://www.researchgate.net/publication/44378898_The_economics_of_the_developin g_countries_Hla_Myint/amp

IMF's (1993). 5th Balance of Payments Manual. https://www.imf.org/external/np/sta/bop/bopman.pdf

Krueger, A. O. (1992). Economic Policy Reform. https://onlinelibrary.wiley.com/doi/abs/10.1002/jid.3380060209

Lahimer, N. (2009). La contribution des IDE à la réduction de la pauvreté en Afrique Sub-saharienne. Thèse de doctorat, Paris: université Paris-Dauphine.

https://basepub.dauphine.fr/bitstream/handle/123456789/1167/These_Lahimer.pdf?seq uence $=1$ \&isAllowed $=y$

UN General Assembly (1993). Vienna Declaration and Programme of Action. https://www.refworld.org/docid/3ae6b39ec.html 